\title{
PRODUCTION AND NUTRITIONAL CHARACTERISTICS OF SUNFLOWERS AND PAIAGUAS PALISADEGRASS UNDER DIFFERENT FORAGE SYSTEMS IN THE OFF SEASON
}

\author{
CARACTERÍSTICAS PRODUTIVAS E NUTRICIONAIS DO GIRASSOL E CAPIM- \\ PAIAGUÁS EM DIFERENTES SISTEMAS FORRAGEIROS NA SAFRINHA
}

\author{
Charles Barbosa SANTOS ${ }^{1}$; Kátia Aparecida de Pinho COSTA²; \\ Itamar Pereira de OLIVEIRA ${ }^{1}$; Eduardo da Costa SEVERIANO ${ }^{1}$; \\ Raoni Ribeiro Guedes Fonseca COSTA ${ }^{1}$; Alessandro Guerra da SILVA ${ }^{2}$; \\ Analu GUARNIERI ; Jessika Torres da SILVA ${ }^{3}$
}

1. PhD candidates from the Postgraduate Program in Agricultural Sciences - Agronomy - Federal Institute of Goiás; Rio Verde, GO, Brazil; 2. Professors, Postgraduate Program in Agricultural Sciences, Agronomy, Federal Institute of Goiás, Rio Verde, GO, Brazil; 3. Graduate student in Animal Science, Federal Institute of Goiás, Rio Verde, GO, Brazil.

\begin{abstract}
The high efficiency of sunflowers in extracting water from the soil under water stress conditions is a factor that promotes sunflower cultivation in the offseason. Therefore, sunflowers have been intercropped with grasses of the Urochloa genus in crop-livestock integration systems. However, little is known of sowing methods for intercropping; thus, the present study aimed to assess sunflower agronomic traits and the production and nutritional characteristics of Paiaguas palisadegrass under different forage systems in the offseason in the midwest region of Brazil. The experiment was conducted at the Federal Institute of Goiás (Instituto Federal Goiano), Rio Verde Campus in a randomized block experimental design with four replicates. The treatments consisted of the following forage systems: sunflower monocropped; Paiaguas palisadegrass monocropped; sunflower rows intercropped with Paiaguas palisadegrass; sunflower inter-row intercropped with Paiaguas palisadegrass; and sunflower oversown and intercropped with Paiaguas palisadegrass. The results show that the sunflower rows intercropped with Paiaguas palisadegrass negatively affect the agronomic traits of sunflower; thus, inter-row sowing and oversowing are recommended. Sowing Paiaguas palisadegrass with oversown sunflower for forage production is hampered by intercropping and shows low forage production. In turn, the intercropped sowing method had no effect on the nutritional characteristics of the produced forage. Intercropping sunflowers with Paiaguas palisadegrass in the offseason has the potential to provide a promising cropping method for the production of achenes and after harvest enables the availability of forage with good nutritional value for use in the offseason in the midwest region of Brazil.
\end{abstract}

KEYWORDS: Urochloa brizantha. Helianthus annuus L. Crop-livestock integration.

\section{INTRODUCTION}

From an agricultural perspective, the sunflower crop has desirable traits, including a short cycle, high quality and good oil yield (CASTRO; FARIAS, 2005). Furthermore, the high efficiency of sunflowers in extracting water from the soil under water stress conditions and their tolerance to a wide temperature range without noticeable effects on production are factors that promote sunflower cultivation in the offseason (BRIGHENTI et al., 2008).

Another key factor for sunflower cultivation in the offseason is the choice of achene for oil production, which has a higher market value than soybean oil for human nutrition and decreases the idleness of beneficiary industries, thus optimizing the use of land, machinery and manpower (CAPONE et al., 2011).
Currently, an increased preference has been observed in Brazil for sunflower, which has been gaining ground, especially in offseason planting. In the 2013/2014 crop year in the midwest region, the planted area of sunflower was 131.1 thousand hectares, with a yield of 212 thousand tons (Conab, 2014). Producer interest in sunflower planting has increased because this crop has multiple uses, such as human nutrition; ruminant, bird and pig feed; forage; edible oil industry raw material; and biofuel (SANTOS et al., 2012).

Sunflower has been recently used as an alternative annual crop in crop-livestock integration systems (BRIGHENTI et al., 2008; SOUZA et al., 2015), and promising results have been observed from intercropping with Xaraes palisadegrass, Piata palisadegrass and massai grasses (GONTIJO NETO et al., 2009), showing that intercropping may be recommended to producers as a method of product 
and income diversification by intensifying crop production in the same area.

Further information on sunflower intercropping conditions is required because of the arrival of a new cultivar of Urochloa brizantha, BRB Paiaguás. This new cultivar is a key alternative for diversifying areas currently under Urochloa brizantha cv. Marandu monocropping, and it will provide significant advantages for crop-livestock integration systems. Furthermore, the main advantage of BRS Paiaguás is observed during the dry season, when it shows an increased accumulation of forage with higher nutritional value and increased productivity per year (Embrapa, 2015).

Thus, the identification of the intercropping combination of Paiaguas palisadegrass with sunflowers will enable achene exploitation and forage production in the offseason. However, studies assessing the appropriate sowing method for intercropping systems are rare. Therefore, the present study aimed to evaluate sunflower agronomic traits and the production and nutritional characteristics of Paiaguas palisadegrass under different forage systems in the offseason in the midwest region of Brazil.

\section{MATERIAL AND METHODS}

The experiment was conducted in the field $\left(17^{\circ} 48^{\prime} \mathrm{S} ; 50^{\circ} 55^{\prime} \mathrm{W}\right.$; and $748 \mathrm{~m}$ altitude) at the Federal Institute of Goiás (Instituto Federal Goiano) in the municipality of Rio Verde, Goiás in the 2014 offseason on a dystroferric Red Latosol soil (Embrapa, 2013).

Soil samples were collected from the $0-20$ $\mathrm{cm}$ layer to assess the physical and chemical characteristics of the experimental area prior to planting the forage systems. The following values were obtained: clay, $520 \mathrm{~g} \mathrm{~kg}^{-1}$; silt, $150 \mathrm{~g} \mathrm{~kg}^{-1}$; sand, $330 \mathrm{~g} \mathrm{~kg}^{-1} ; \mathrm{pH}$ in $\mathrm{CaCl}_{2}: 5.02$; $\mathrm{Ca}: 4.62 \mathrm{cmol}_{\mathrm{c}}$ $\mathrm{dm}^{-3} ; \mathrm{Mg}: 1.24 \mathrm{cmol}_{\mathrm{c}} \mathrm{dm}^{-3}$; $\mathrm{Al}: 0.01 \mathrm{cmol}_{\mathrm{c}} \mathrm{dm}^{-3}$; $\mathrm{Al}+\mathrm{H}: 6.00 \mathrm{cmol}_{\mathrm{c}} \mathrm{dm}^{-3}$; K: $0.63 \mathrm{cmol}_{\mathrm{c}} \mathrm{dm}^{-3}$; CEC: $12.52 \mathrm{cmol}_{\mathrm{c}} \mathrm{dm}^{-3}$; P: $8.43 \mathrm{~g} \mathrm{dm}^{-3}$; Cu: $3.5 \mathrm{~g} \mathrm{dm}^{-3}$; $\mathrm{Zn}: 4.1 \mathrm{~g} \mathrm{dm}^{-3}$; Fe: $34.0 \mathrm{~g} \mathrm{dm}^{-3}$; and organic matter (O.M.): $36.76 \mathrm{~g} \mathrm{~kg}^{-1}$.

The experimental design consisted of randomized blocks with four replicates and used the following forage systems: sunflower monocropped; Paiaguas palisadegrass monocropped; sunflower row-intercropped with Paiaguas palisadegrass; sunflower inter-row intercropped with Paiaguas palisadegrass; and sunflower oversown and intercropped with Paiaguas palisadegrass. There were 20 experimental plots, and Charrua (triple, semi-early, black-achene hybrid with high oil content) was the sunflower cultivar.

Tillage was performed by weed desiccation using the herbicide glyphosate at a dose of $1.680 \mathrm{~g}$ active ingredient (a.i.) ha $^{-1}$ glyphosate in a volume of $150 \mathrm{~L}$ broth $\mathrm{ha}^{-1}$. Disking was performed at $40 \mathrm{~cm}$ 20 days after desiccation using a disk harrow to remove the seed bank of colonião grass and weeds in the area.

A week before planting, $1.0 \mathrm{t} \mathrm{ha}^{-1}$ limestone filler was applied, and the second disking operation was performed at $20 \mathrm{~cm}$ followed by leveling. Subsequently, sowing furrows were opened using a planter, and the sowing furrows of Paiaguas palisadegrass in sunflower inter-rows and oversowing plots were manually opened using hoes.

Sowing was performed on 02/17/2014 using $80 \mathrm{~kg} \mathrm{ha}^{-1} \mathrm{P}_{2} \mathrm{O}_{5}, 20 \mathrm{~kg} \mathrm{ha}^{-1}$ FTE BR 12 and $1.5 \mathrm{~kg}$ boron and triple super phosphate, frits and boric acid as sources. The sunflowers were sown to a depth of $3 \mathrm{~cm}$ in the row, inter-row and oversowing intercropping and monocropping. The Paiaguas palisadegrass was sown to a depth of $6 \mathrm{~cm}$ in the row intercropping and to a depth of $40 \mathrm{~cm}$ from the sunflower row in the inter-row intercropping. In the oversowing intercropping, Paiaguas palisadegrass was sown 15 days after the emergence (DAE) of sunflowers in the inter-rows at $40 \mathrm{~cm}$. Sunflower seeds at $6 \mathrm{~kg} \mathrm{~m}^{-1}$ and pure and viable Paiaguas palisadegrass seeds at $5 \mathrm{~kg} \mathrm{ha}^{-1}$ were used. The plots consisted of eight rows $3.0 \mathrm{~m}$ long in all forage systems.

Manual weeding was performed weekly up to $50 \mathrm{DAE}$ for weed control. Pest control was manually performed on $03 / 25 / 2014$ by applying the insecticides Losban (contact) and Nomolt (physiological) at doses of 120 and $7.5 \mathrm{~g}$ a.i. $\mathrm{ha}^{-1}$ to control the sunflower patch (Chlosyne lacinia saundersii) and southern armyworm (Spodoptera eridania), respectively, and the fungicide Prior extra on $04 / 07 / 2014$ at a dose of $60+24 \mathrm{~g}$ a.i. $\mathrm{ha}^{-1}$ to control sunflower leaf blight (Alternaria helianthi) and powdery mildew (Erysiphe cichoracearum). Rainfall and monthly average temperature data were monitored daily during the experimental period (Figure 1).

The agronomic traits assessed for intercropped and monocropped sunflowers included plant height (measured from the base of the plant to the receptacle in ten randomly chosen plants), stem diameter (using a digital caliper accurate to 0.01 $\mathrm{mm}$ ) and leaf number per plant at 30,60 and 90 DAE. 


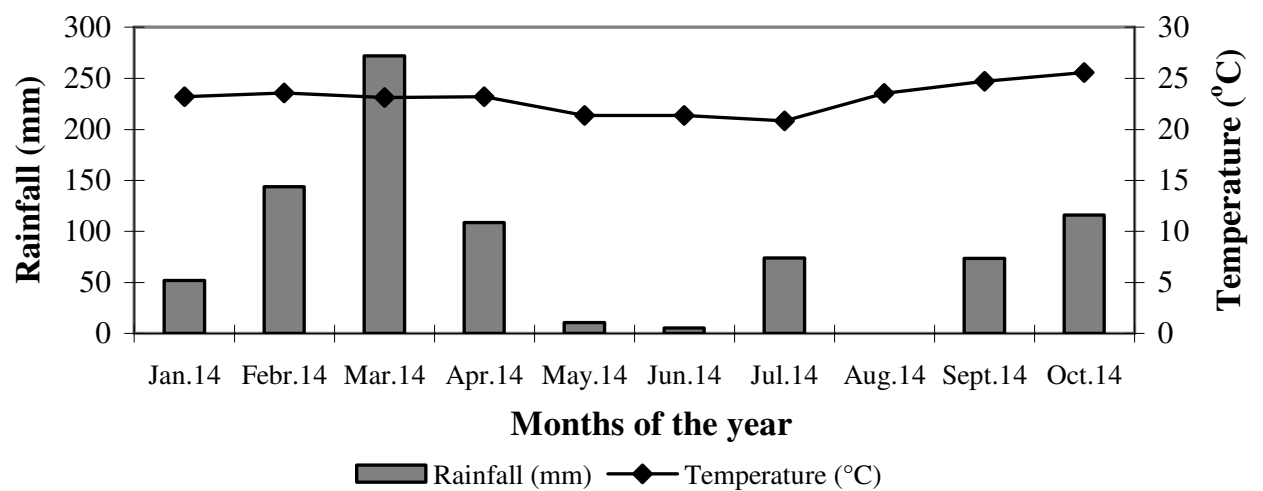

Figure 1. Rainfall and average temperatures recorded from January to October 2014 in Rio Verde, Goiás (GO).

Harvest was performed manually at 130 DAE at the time when the plants reached the physiological maturity stage, and the following parameters were assessed in the useful area of the plot at harvest: head diameter was measured in ten randomly chosen plants; dry mass yield from the stem and leaf collection from all plot plants was determined by placing the plant material in an oven at $55^{\circ} \mathrm{C}$ until a constant mass was reached, with the dry weight converted to $\mathrm{kg} \mathrm{ha}^{-1} ; 1000$-achene mass was determined by weighing 1000 achenes and was expressed in grams, with the moisture adjusted to 13\%; and achene productivity was determined by threshing the heads, weighing the achenes, adjusting the moisture to $13 \%$ and converting the data to $\mathrm{kg}$ ha $^{-1}$.

Seed oil levels were assessed by the chemical method using hexane as an extractor, and the oil productivity was calculated by multiplying the achene oil levels, expressed as \%, and achene productivity, expressed as $\mathrm{kg} \mathrm{ha}^{-1}$ (UCHÔA et al., 2011).

The dry mass yield and nutritional value of Paiaguas palisadegrass were assessed after the sunflower harvest until the beginning of the rainy season (September). Forage plants were assessed under conditions of successive cuts, with $1 \mathrm{~m}^{2}, 20$ $\mathrm{cm}$ high samples collected from random directions within a square within each plot.

The first cut was performed at sunflower harvest on 06/17/2014, and the second cut was performed 71 days after the first cut on 08/26/2014; the reduced forage growth in the low rainfall period was considered a dry season. The standardization cut of all plants of the experimental area was performed following both evaluation cuts at the same height of the evaluated plants. The residues resulting from standardization were then removed from the area. Subsequently, the Paiaguas palisadegrass was left standing for regrowth and desiccation to generate the sunflower trash for soybean planting in the next season.

The collected material was stored in plastic bags and sent to the laboratory, and a sample $(500 \mathrm{~g})$ representative of each plot was removed and placed in a forced-air convection oven at $55{ }^{\circ} \mathrm{C}$ for pre-drying. Subsequently, the samples were ground in a Willey mill with a millimeter diameter sieve and stored in plastic pots for further analysis.

The bromatological analyses were performed to assess the dry matter (DM), crude protein $(\mathrm{CP})$, neutral detergent fiber (NDF) and acid detergent fiber (ADF), using the method reported by Silva and Queiroz (2002). In vitro dry matter digestibility (IVDMD) was assessed using the method described by Tilley and Terry (1963) and adapted to the artificial rumen developed by ANKON $^{\circledR}$ using the "Daisy incubator" device from Ankom Technology (in vitro true digestibilityIVTD). The collection of rumen fluid was performed using two rumen-fistulated male cattle with an average weight of $450 \mathrm{~kg}$; the animals were maintained on xaraés pasture.

The data were subjected to an analysis of variance (ANOVA), and the means were compared according to Tukey's test at 5\% probability using SISVAR 4.6 statistical software (Ferreira, 2011).

\section{RESULTS AND DISCUSSION}

\section{Sunflower crop}

Plant heights at 30,60 and 90 days after sowing (DAS) were not affected $(\mathrm{P}>0.05)$ by the forage systems (Table 1), showing that intercropping sunflowers with Paiaguas palisadegrass using different sowing methods had no effect on sunflower growth, which suggests that intercropping may be viable, especially for pasture growth and in critical periods of drought, with 
sunflower trash supplied for use in the no-tillage system.

The plant height at 60 and 90 DAS was within the range reported by Santos et al. (2012). However, the plant height was higher than the values reported in the study by Souza et al. (2015), who evaluated sunflower intercropped with Urochloa ruziziensis in the offseason in the municipality of Dourados, state of Mato Grosso do Sul (MS).

Table 1. Plant height at 30,60 and 90 DAS of sunflowers monocropped and intercropped with Paiaguas palisadegrass under different forage systems.

\begin{tabular}{lccc}
\hline Forage systems & 30 DAS $(\mathbf{c m})$ & 60 DAS $(\mathbf{c m})$ & 90 DAS $(\mathbf{c m})$ \\
\hline Monocropped sunflowers & $28.70 \mathrm{a}$ & $184.54 \mathrm{a}$ & $194.00 \mathrm{a}$ \\
Row sunflowers x Paiaguas palisadegrass & $28.80 \mathrm{a}$ & $169.96 \mathrm{a}$ & $179.25 \mathrm{a}$ \\
Inter-row sunflowers x Paiaguas palisadegrass & $27.91 \mathrm{a}$ & $179.91 \mathrm{a}$ & $189.45 \mathrm{a}$ \\
Oversown sunflowers x Paiaguas palisadegrass & $29.16 \mathrm{a}$ & $186.12 \mathrm{a}$ & $186.30 \mathrm{a}$ \\
CV $(\%)$ & 6.08 & 4.05 & 2.72 \\
\hline
\end{tabular}

Means followed by different letters differ according to Tukey's test at 5\% probability.

Significant differences $(\mathrm{P}>0.05)$ were not observed between forage systems for stem diameter assessed at 30 DAS. However, sunflowers rowintercropped with Paiaguas palisadegrass negatively affected $(\mathrm{P}<0.05)$ stem diameter, with lower values observed at 60 and 90 DAS (Table 2). This result may have been caused by plant competition for water, light and nutrients in the row intercropping treatment, suggesting that this sowing method is not appropriate for intercropping with sunflowers.

Table 2. Stem diameter at 30,60 and 90 DAS of sunflowers monocropped and intercropped with Paiaguas palisadegrass under different forage systems.

\begin{tabular}{lccc}
\hline Forage systems & 30 DAS (mm) & 60 DAS (mm) & 90 DAS (mm) \\
\hline Monocropped sunflowers & $0.12 \mathrm{a}$ & $0.35 \mathrm{a}$ & $38.63 \mathrm{a}$ \\
Row sunflowers x Paiaguas palisadegrass & $0.10 \mathrm{a}$ & $0.30 \mathrm{~b}$ & $33.15 \mathrm{~b}$ \\
Inter-row sunflowers x Paiaguas palisadegrass & $0.10 \mathrm{a}$ & $0.35 \mathrm{a}$ & $37.69 \mathrm{a}$ \\
Oversown sunflowers x Paiaguas palisadegrass & $0.12 \mathrm{a}$ & $0.37 \mathrm{a}$ & $38.15 \mathrm{a}$ \\
CV $(\%)$ & 9.30 & 4.88 & 5.72 \\
\hline
\end{tabular}

Means followed by different letters differ according to Tukey's test at $5 \%$ probability.

Stem diameter is a key parameter for achene production because it is related to plant lodging, with larger stem diameters reducing the likelihood of lodging, which facilitates plant management and harvest (BISCARO et al., 2008) and may provide a greater number and size of achenes.

The results outlined in Table 3 indicate that the forage system did not have an effect on leaf number at 30 DAS, and the results were similar $(\mathrm{P}>0.05)$. However, the forage systems affected
$(\mathrm{P}<0.05)$ the leaf number at 60 DAS for sunflowers row and inter-row intercropped with Paiaguas palisadegrass, which resulted in lower leaf numbers. However, only row intercropping resulted in lower leaf number at 90 DAS, which was likely caused by a competition effect similar to stem diameter. Urochloa grasses show extensive root systems and are more aggressive (BRIGHENTI et al., 2008), which contributes to an increased competition effect within the same planting row.

Table 3. Leaf number at 30,60 and 90 DAS of sunflowers monocropped and intercropped with Paiaguas palisadegrass under different forage systems.

\begin{tabular}{lccc}
\hline Forage systems & 30 DAS & 60 DAS & 90 DAS \\
\hline Monocropped sunflowers & $8.26 \mathrm{a}$ & $21.26 \mathrm{a}$ & $19.46 \mathrm{a}$ \\
Row sunflowers x Paiaguas palisadegrass & $7.93 \mathrm{a}$ & $18.50 \mathrm{~b}$ & $16.16 \mathrm{~b}$ \\
Inter-row sunflowers x Paiaguas palisadegrass & $8.06 \mathrm{a}$ & $19.16 \mathrm{~b}$ & $18.53 \mathrm{a}$ \\
Oversown sunflowers x Paiaguas palisadegrass & $8.43 \mathrm{a}$ & $21.36 \mathrm{a}$ & $1983 \mathrm{a}$ \\
CV $(\%)$ & 4.42 & 4.88 & 12.35 \\
\hline
\end{tabular}

Means followed by different letters differ according to Tukey's test at 5\% probability.

Karadoðan and Akgün (2009) reported that leaf growth and development have a strong effect on plant yield and play a key role in the species ability to control water loss. The leaf is the main photosynthetic apparatus, and it accumulates nutrients and organic compounds for translocation 
to the reproductive organs and grains, thus helping the plants reach higher achene productivity, oil content and crude protein levels (LIMA JUNIOR et al., 2010).

Table 4 shows that the highest values were obtained with sunflowers monocropped and oversown intercropped with Paiaguas palisadegrass, with the results only showing differences $(\mathrm{P}<0.05)$ in row intercropping when the head diameter at harvest and 1000-achene weight were assessed. Backes et al. (2008) evaluated the performance of sunflower cultivars at two planting periods in the offseason and observed a mean of $46.3 \mathrm{~g}$ per 1000achene weight. These values were similar to those obtained for the mean of the forage systems $(50.9 \mathrm{~g})$ of this study.

Table 4. Head diameter at harvest, 1000-achene weight and achene productivity of sunflowers monocropped and intercropped with Paiaguas palisadegrass under different forage systems.

\begin{tabular}{lccc}
\hline Forage systems & $\begin{array}{c}\text { Head diameter } \\
(\mathrm{cm})\end{array}$ & $\begin{array}{c}\text { 1000-achene } \\
(\mathrm{g})\end{array}$ & $\begin{array}{c}\text { Achene productivity } \\
(\mathrm{kg})\end{array}$ \\
\hline Monocropped sunflowers & $19.88 \mathrm{a}$ & $55.78 \mathrm{a}$ & $3.825 \mathrm{a}$ \\
Row sunflowers x Paiaguas palisadegrass & $15.57 \mathrm{~b}$ & $46.10 \mathrm{~b}$ & $2.946 \mathrm{~b}$ \\
Inter-row sunflowers x Paiaguas palisadegrass & $17.75 \mathrm{ab}$ & $49.72 \mathrm{ab}$ & $3.511 \mathrm{a}$ \\
Oversown sunflowers x Paiaguas palisadegrass & $20.70 \mathrm{a}$ & $52.29 \mathrm{a}$ & $3.556 \mathrm{a}$ \\
CV $(\%)$ & 14.19 & 12.33 & 13.53 \\
\hline
\end{tabular}

Means followed by different letters differ according to Tukey's test at 5\% probability.

Sunflowers that were oversown and intercropped with Paiaguas palisadegrass were similar to monocropped sunflowers in all assessed variables because of the reduced growth of Paiaguas palisadegrass when sown at 15 DAE of sunflowers, which resulted from the large leaf area of the sunflowers causing shading over the grass.

Treatments with sunflowers that were rowintercropped with Paiaguas palisadegrass showed a negative effect on $(\mathrm{P}<0.05)$ achene productivity and caused a $23.2 \%$ reduction compared with the mean of the other forage systems (Table 4), showing the greater competition of Paiaguas palisadegrass with sunflower plants in this sowing method; this result was previously observed for other variables, such as leaf number and stem diameter, which directly affected the results of 1000-achene weight and achene productivity.
The mean achene productivity obtained in the present study was higher than that reported by Souza et al. (2015), who observed a yield of 1.470 $\mathrm{kg} \mathrm{ha}^{-1}$ for monocropped sunflowers and $1.400 \mathrm{~kg}$ $\mathrm{ha}^{-1}$ for the intercropping system with Urochloa ruziziensis under offseason conditions in Dourados, MS, Brazil.

The treatment with sunflowers rowintercropped with Paiaguas palisadegrass showed changes in the $(\mathrm{P}<0.05)$ dry mass yield $($ leaf + stem) of sunflowers (Table 5), and the leaf number and stem diameter at harvest were also noticeably smaller at 60 and 90 DAS, which contributed to the reduced amount of sunflower dry mass. According to Gomes et al. (2010), stem growth is the component that has the greatest effect on dry mass accumulation.

Table 5. Dry mass yield (DM yield), oil levels and productivity of sunflowers monocropped and intercropped with Paiaguas palisadegrass under different forage systems.

\begin{tabular}{lccc}
\hline Forage systems & $\begin{array}{c}\text { DM yield } \\
\left(\mathrm{kg} \mathrm{ha}^{-1}\right)\end{array}$ & $\begin{array}{c}\text { Oil levels } \\
(\%)\end{array}$ & $\begin{array}{c}\text { Oil yield } \\
\left(\mathrm{kg} \mathrm{ha}^{-1}\right)\end{array}$ \\
\hline Monocropped sunflowers & $2.384 \mathrm{a}$ & $60.44 \mathrm{a}$ & $2.321 \mathrm{a}$ \\
Row sunflowers x Paiaguas palisadegrass & $1.762 \mathrm{~b}$ & $50.88 \mathrm{~b}$ & $1.707 \mathrm{~b}$ \\
Inter-row sunflowers x Paiaguas palisadegrass & $2.370 \mathrm{a}$ & $60.60 \mathrm{a}$ & $2.129 \mathrm{ab}$ \\
Oversown sunflowers x Paiaguas palisadegrass & $2.189 \mathrm{a}$ & $56.69 \mathrm{ab}$ & $2.016 \mathrm{ab}$ \\
$\mathrm{CV}(\%)$ & 13.86 & 3.17 & 14.03 \\
\hline
\end{tabular}

Means followed by different letters differ according to Tukey's test at 5\% probability.

Lobo et al. (2012) reported that the mean productivity of dry mass is a key parameter because it reflects the quantity of plant biomass that may return to the soil after harvesting the grain. This biomass retention may be beneficial to the subsequent crops because of increased moisture retention and improved temporal availability of soil nutrients related to rapid leaf and head decomposition, given the low $\mathrm{C} / \mathrm{N}$ ratio, with the opposite result observed for the stems. Accordingly, 
the sowing methods of Paiaguas palisadegrass when inter-row and oversown intercropped showed higher dry mass yield because of the reduced competition effect.

Table 5 shows that the lowest oil levels and productivity were obtained in the row intercropping treatment, with 16.4 and $26.4 \%$ reductions, respectively, compared with the mean of the other forage systems, suggesting that this sowing method is not appropriate for intercropping with sunflowers. This result is relevant because sunflower oil is considered one of the best quality oils; therefore, the sunflower crop has gained popularity in agriculture because of its efficient oil extraction for biodiesel production (Gama et al., 2010). Therefore, selecting the correct sowing method in intercropping systems has an important effect on the final sunflower production.

The results show that even under intercropping conditions where a greater competition for light, water and nutrients occurred, sunflowers were not affected by the presence of
Paiaguas palisadegrass in the inter-row and oversown intercropped systems, indicating the importance of the crop-livestock integration system for achene production.

\section{Urochloa crop}

The Paiaguas palisadegrass height was affected $(\mathrm{P}<0.05)$ by the forage system at both cuts (Table 6). The lowest height of the first cut was obtained when sunflowers were oversown and intercropped with Paiaguas palisadegrass, showing that this planting method impaired the growth of Paiaguas palisadegrass because the grass was planted 15 DAS the sunflowers, which resulted in increased shading from the sunflowers in the initial germination stage of Paiaguas palisadegrass. However, the height of the plants in the intercropped systems was similar at the second cut after the sunflower harvest, with the results only showing a difference with the monocropped Paiaguas palisadegrass.

Table 6. Plant height, tiller number and dry mass yield of Paiaguas palisadegrass monocropped and intercropped with sunflowers under different forage systems.

\begin{tabular}{|c|c|c|}
\hline \multirow[t]{2}{*}{ Forage systems } & $1^{\text {st }}$ Cut & $2^{\text {nd }}$ Cut \\
\hline & \multicolumn{2}{|c|}{ Plant Height $(\mathrm{cm})$} \\
\hline Monocropped Paiaguas palisadegrass & $84.15 \mathrm{Aa}$ & $69.30 \mathrm{Ab}$ \\
\hline Row sunflowers x Paiaguas palisadegrass & $67.20 \mathrm{Ba}$ & $40.07 \mathrm{Bb}$ \\
\hline Inter-row sunflowers x Paiaguas palisadegrass & $82.35 \mathrm{Aa}$ & $40.05 \mathrm{Bb}$ \\
\hline Oversown sunflowers x Paiaguas palisadegrass & $49.75 \mathrm{Ca}$ & $38.00 \mathrm{Bb}$ \\
\hline CV $(\%)$ & & \\
\hline
\end{tabular}

Monocropped Paiaguas palisadegrass

Row sunflowers x Paiaguas palisadegrass

Inter-row sunflowers x Paiaguas palisadegrass

Oversown sunflowers $\mathrm{x}$ Paiaguas palisadegrass

$\mathrm{CV}(\%)$

Monocropped Paiaguas palisadegrass

Row sunflowers x Paiaguas palisadegrass

Inter-row sunflowers x Paiaguas palisadegrass

Oversown sunflowers x Paiaguas palisadegrass

CV (\%)

$364.00 \mathrm{Aa}$
$179.50 \mathrm{Ba}$
$186.25 \mathrm{Ba}$
$111.00 \mathrm{Ca}$

Tiller Number

$281.50 \mathrm{Ab}$

$159.15 \mathrm{Ba}$

$160.50 \mathrm{Ba}$

$145.70 \mathrm{Bb}$

14.85

Means followed by different uppercase letters in columns (forage systems) and lowercase letters in rows (cut) differ according to Tukey's test at $5 \%$ probability.

Similar results were observed by Cruz et al. (2008), who evaluated Urochloa decumbens monocropped and intercropped with maize. The authors observed that maize affected forage growth, which showed slower initial growth than monocropped Urochloa.

Plant height was noticeably higher at the first cut for all forage systems (Table 6). The greater growth of Paiaguas palisadegrass at the first cut may be correlated with greater rainfall distribution in March and April (Figure 1). However, at the second cut after the sunflower harvest, low rainfall was observed, thus impairing leaf blade growth.

The results outlined in Table 6 show that the highest tiller numbers were obtained in monocropped Paiaguas palisadegrass for both cuts. 
Among the different forms of sowing, oversown and intercropped Paiaguas palisadegrass with sunflowers had the greatest effect on the emergence of tillers, which was because of the low amount of light available to Paiaguas palisadegrass as a result of the large leaf area of sunflowers impairing the emergence and growth of new lateral buds that lead to the development of new tillers. Only monocropped and oversown intercropped Paiaguas palisadegrass were affected at the cuts, with a reduced number of tillers shown at the second cut.

When evaluating dry mass yield, the production of Paiaguas palisadegrass was noticeably similar in the row and inter-row intercropping systems, with these results differing from the monocropping and oversown intercropping systems at both cuts (Table 6). The lowest production was obtained with oversown Paiaguas palisadegrass intercropped with sunflowers, suggesting that this is not the best planting method because it drastically affects forage production. These results show that Paiaguas palisadegrass is intolerant to the shading caused by sunflower plants, which results in low forage production for use in the offseason. Similar results were obtained by Gontijo Neto et al. (2009), who worked with sunflower intercropped with xaraés, piatã and massai grasses and observed that sunflower affected forage production, with a $66 \%$ reduction for xaraés grasses and an approximately $50 \%$ reduction for Piata palisadegrass and massai grasses.

When comparing the cuts in all forage systems, the lowest dry matter yield was obtained at the first cut. In the crop-livestock integrated system after harvest, the area is used as pasture for grazing. Thus, forage selected for intercropping must be appropriate for grain production of the annual crop and present adequate establishment and growth when intercropped. Under the conditions of the present study, even after sunflower harvest, forage production at the second cut was lower because of the low water availability (Figure 1) in the offseason, which is common in the midwest region. This result indicates that sunflowers intercropped with Paiaguas palisadegrass in the same area is an effective cropping method for developing low-cost pastures despite obtaining low forage production in the dry season.

The mean dry mass yield of Paiaguas palisadegrass at the first and second cuts was 3.110 and $2.218 \mathrm{~kg} \mathrm{ha}^{-1}$, respectively, and these values are lower than those observed by Machado and Valle et al. (2011), who evaluated the agronomic performance of Urochloa grass genotypes grown after soybean and obtained a yield of $5.318 \mathrm{~kg}$ ha ${ }^{1}$ for Paiaguas palisadegrass (B6 line).

Crude protein levels were not affected ( $P>0.05)$ by the forage systems at the first cut. However, the highest levels at the second cut were obtained with sunflowers oversown and intercropped with Paiaguas palisadegrass (Table 7). The crude protein levels obtained in the present study at the first and second cuts were similar to those found by Maia et al. (2014), who obtained mean crude protein levels ranging between 9.0 and $13.4 \%$ in September and October, respectively, when evaluating the bromatological composition of forages of the Urochloa genus in the offseason after corn harvest in a crop-livestock integrated system.

A comparison of the cuts in all forage systems showed that the lowest crude protein levels were obtained at the first cut (Table 7). This result is related to the forage vegetative cycle because the first cut was performed during sunflower harvest in the 120-day cycle, and by this time, the Paiaguas palisadegrass had already passed on to the forage maturation stage, thus reducing crude protein levels. At the second cut, the Paiaguas palisadegrass was cut at the 71-day growth.

Significant effects $(\mathrm{P}>0.05)$ were not observed among forage systems and cuts for the neutral detergent fiber levels (Table 7). The neutral detergent fiber levels ranged between 69.04 and $65.63 \%$ at the first and second cuts, respectively, showing similarities with the values obtained in other studies of maize intercropping with Marandu palisadegrass (Pariz et al., 2011; Pariz et al., 2010).

Table 7 shows that the acid detergent fiber levels were similar among forage systems at the first and second cuts. However, the second cut showed lower acid detergent fiber levels than the first because the second cut was performed in the lower growth cycle. Furthermore, tiller emission was resumed after sunflower harvest, which was also affected by the beginning of the rainy season, thus providing forage with improved digestibility. This result shows that in the offseason period, which has low forage production and quality, intercropping sunflowers with Paiaguas palisadegrass may be considered an excellent alternative for use in the crop-livestock integration system.

The forage systems had no effect $(\mathrm{P}>0.05)$ on the IVDMD levels, with similar results observed between the first and second cuts (Table 7). However, higher levels were obtained at the second cut compared with the first, which may have been caused by increased digestibility at the second cut associated with modifications in the chemical 
composition of the fraction with the decrease in

ADF levels.

Table 7. Crude protein (CP), neutral detergent fiber (NDF), acid detergent fiber (ADF) and in vitro dry matter digestibility (IVDMD) levels of Paiaguas palisadegrass monocropped and intercropped with sunflowers under different forage systems.

\begin{tabular}{lcc}
\hline Forage systems & $\mathbf{1}^{\text {st }} \mathbf{C u t}$ & $\mathbf{2}^{\text {nd }} \mathbf{C u t}$ \\
\cline { 2 - 3 } & \multicolumn{2}{c}{ CP levels (\%) } \\
\hline Monocropped Paiaguas palisadegrass & $10.53 \mathrm{Ab}$ & $13.69 \mathrm{Aa}$ \\
Row sunflowers x Paiaguas palisadegrass & $9.97 \mathrm{Ab}$ & $13.52 \mathrm{Aa}$ \\
Inter-row sunflowers x Paiaguas palisadegrass & $10.20 \mathrm{Ab}$ & $13.75 \mathrm{Aa}$ \\
Oversown sunflowers x Paiaguas palisadegrass & $10.60 \mathrm{Ab}$ & $12.04 \mathrm{Ba}$ \\
$\mathrm{CV}(\%)$ & $\ldots \ldots \ldots \ldots \ldots \ldots \ldots . .5 .65 \ldots \ldots \ldots \ldots \ldots \ldots \ldots$ \\
\hline
\end{tabular}

\begin{tabular}{|c|c|c|}
\hline & \multicolumn{2}{|c|}{ NDF Levels (\%) } \\
\hline Monocropped Paiaguas palisadegrass & $70.72 \mathrm{Aa}$ & $67.38 \mathrm{Aa}$ \\
\hline Row sunflowers x Paiaguas palisadegrass & $67.62 \mathrm{Aa}$ & $65.82 \mathrm{Aa}$ \\
\hline Inter-row sunflowers x Paiaguas palisadegrass & $68.29 \mathrm{Aa}$ & $64.71 \mathrm{Aa}$ \\
\hline Oversown sunflowers x Paiaguas palisadegrass & $69.54 \mathrm{Aa}$ & $64.62 \mathrm{Aa}$ \\
\hline \multirow[t]{2}{*}{$\mathrm{CV}(\%)$} & ................... & $\ldots \ldots \ldots \ldots$ \\
\hline & \multicolumn{2}{|c|}{ ADF Levels (\%) } \\
\hline Monocropped Paiaguas palisadegrass & $46.54 \mathrm{Aa}$ & $39.70 \mathrm{Ab}$ \\
\hline Row sunflowers x Paiaguas palisadegrass & $43.26 \mathrm{Aa}$ & $38.23 \mathrm{Ab}$ \\
\hline Inter-row sunflowers x Paiaguas palisadegrass & $45.39 \mathrm{Aa}$ & $36.81 \mathrm{Ab}$ \\
\hline Oversown sunflowers x Paiaguas palisadegrass & $46.00 \mathrm{Aa}$ & $36.46 \mathrm{Ab}$ \\
\hline \multirow[t]{2}{*}{$\mathrm{CV}(\%)$} & & \\
\hline & \multicolumn{2}{|c|}{ IVDMD Levels (\%) } \\
\hline Monocropped Paiaguas palisadegrass & $50.55 \mathrm{Ab}$ & $61.24 \mathrm{Aa}$ \\
\hline Row sunflowers x Paiaguas palisadegrass & $52.02 \mathrm{Ab}$ & $59.98 \mathrm{Aa}$ \\
\hline Inter-row sunflowers x Paiaguas palisadegrass & $51.11 \mathrm{Ab}$ & $60.64 \mathrm{Aa}$ \\
\hline Oversown sunflowers x Paiaguas palisadegrass & $50.84 \mathrm{Ab}$ & $58.35 \mathrm{Aa}$ \\
\hline CV $(\%)$ & ................. & ................. \\
\hline
\end{tabular}

Means followed by different uppercase letters in columns (forage systems) and lowercase letters in rows (cuts) differ according to Tukey's test at $5 \%$ probability.

In a study evaluating Urochloa brizantha genotypes grown after soybean in a crop-livestock integration system, Machado and Valle (2011) observed higher digestibility levels of 74.9, 74.0, $67.8,71.6,83.7$ and $77.3 \%$ for Marandu palisadegrass, MG-4 palisadegrass, Xaraes palisadegrass, Piata palisadegrass, Arapoty grass and Paiaguas palisadegrass (B6 line), respectively.

\section{CONCLUSIONS}

Sunflowers that were row-intercropped with Paiaguas palisadegrass showed reduced agronomic traits; therefore, inter-row sowing and oversowing are recommended.

For forage production, Paiaguas palisadegrass cultivated with sunflower oversowing was hampered by intercropping and showed low forage production. With regard to forage quality, the sowing method used in the intercropping had no effect on the nutritional characteristics.

Intercropping sunflower with Paiaguas palisadegrass in the offseason is a promising alternative cropping technique for achene production that allows for postharvest availability of forage with good nutritional value for use in the offseason in the midwest region of Brazil.

\section{ACKNOWLEDGMENTS}

We would like to acknowledge the State of Goiás Research Foundation (Fundação de Amparo a Pesquisa do Estado de Goiás, FAPEG) for funding the project. 
RESUMO: A alta eficiência do girassol em utilizar a água disponível no solo para o seu desenvolvimento sob condição de estresse hídrico são fatores que estimulam o cultivo do girassol na safrinha. Com isso, o girassol vem sendo usado em consórcio com gramíneas do gênero Urochloa nos sistemas de integração agricultura-pecuária. No entanto, pouco se conhece sobre a forma de semeadura destas espécies em consórcio. Sendo assim, objetivou-se avaliar as características agronômicas do girassol, bem como as características produtivas e nutricionais do capim-paiaguás em diferentes sistemas forrageiros, na safrinha na região Centro-Oeste. O experimento foi conduzido no Instituto Federal Goiano, Campus Rio Verde, no delineamento experimental em blocos ao acaso com quatro repetições. Os tratamentos foram constituídos dos seguintes sistemas forrageiros: girassol em monocultivo; capim-paiaguás em monocultivo; girassol consorciado com o capim-paiaguás na linha; girassol consorciado com o capim-paiaguás na entrelinha e girassol consorciado com o capim-paiaguás em sobressemeadura. Os resultados mostraram que o consórcio do girassol com o capim-paiaguás na linha afeta negativamente as características agronômicas do girassol, sendo mais recomendando a semeadura na entrelinha e em sobressemeadura. Para a produção de forragem, o capim-paiaguás semeado na sobressemeadura do girassol é prejudicado pelo consórcio, apresentando baixa produção de forragem. Em relação à qualidade de forragem, a forma de semeadura no consórcio, não influenciou nas características nutricionais. O consórcio do girassol com o capim-paiaguás na safrinha mostrou-se uma técnica de cultivo promissora para produção de aquênios e após a colheita possibilita a disponibilidade de forragem com bom valor nutritivo para ser utilizado na entressafra na região Centro-Oeste do Brasil.

PALAVRAS-CHAVE: Urochloa brizantha. Helianthus annuus L. Integração agricultura-pecuária.

\section{REFERENCES}

BACKES, R. L.; SOUZA, A. M.; BALBINOT JUNIOR, A. A.; GALLOTTI, G. J. M.; BAVARESCO, A. Desempenho de cultivares de girassol em duas épocas de plantio de safrinha no planalto norte catarinense. Scientia Agrária, Curitiba, v. 09, n. 01, p. 41-48, 2008. http://dx.doi.org/10.5380/rsa.v9i1.10131

BISCARO, G. A.; MACHADO, J. R.; TOSTA, M. S.; MENDONÇA, V.; SORATTO, R. P.; CARVALHO, L. A. Adubação nitrogenada em cobertura no girassol irrigado nas condições de Cassilândia-MS. Ciência e Agrotecnologia, Lavras, v. 32, n. 05, p. 1366-1373, 2008. http://dx.doi.org/10.1590/S141370542008000500002

BRIGHENTI, A. M.; SOBRINHO, F. S.; COSTA, T. R.; ROCHA, W. S. D.; MARTIN C. E.; FERREIRA, L. H. C. Integração Lavoura-Pecuária: A cultura do sunflower consorciada com Brachiaria ruzizienses. Embrapa Gado de Leite, Juiz de Fora MG. [s.n.], 2008. p.10 (Embrapa Gado de Leite. Circular Técnica, 96).

CASTRO, C.; FARIAS, J. R. B. Ecofisiologia do sunflower. In: LEITE, R. M. V. B. C.; BRIGHENTI, A. M.; CASTRO, C. (Ed), Girassol no Brasil. Embrapa soja, 2005. p. 163-210.

CAPONE, A.; BARROS, H. B.; SANTOS, E. R.; SANTOS, A. F.; FERRAZ, E. C.; FIDELIS, R. R. Épocas de semeadura de girassol safrinha após milho, em plantio direto no Cerrado Tocantinense. Revista Brasileira de Ciências Agrárias, Pernambuco, v. 6, n. 3, 2011, p. 460-466, 2011.

http://dx.doi.org/10.5039/agraria.v6i3a1151

CONAB, Levantamento da safra 2013/2014. Disponível em: <www.conab.gov.br>. Acesso em: 06 nov. 2014.

CRUZ, S. C. S.; PEREIRA, F. R. S.; BICUDO, S. J.; ALBUQUERQUE, A. W.; SANTOS, J. R.; MACHADO, C. G. Nutrição do milho e da Brachiaria decumbens cultivados em consórcio em diferentes preparos do solo. Acta Scientiarum Agronomy, Maringá, v. 30, p. 733-739, 2008, suplemento.

http://dx.doi.org/10.4025/actasciagron.v30i5.5975

EMBRAPA SOLOS - EMPRESA BRASILEIRA DE PESQUISA AGROPECUÁRIA -EMBRAPA. Centro Nacional de Pesquisa de Solos. Sistema Brasileiro de Classificação de Solos. Embrapa CNPS, 3 ed. Rio de Janeiro, 2013. 353p. 
EMBRAPA. BRS Paiaguás, uma nova força para a pecuária. Disponível em: $<$ http://cnpgc.embrapa.br/mkt/Folder-Paiaguas-Final-EmbrapaeUnipasto.pdf. 2014 >Acesso em: 31 janeiro 2015.

FERREIRA, D. F. Sisvar: a computer statistical analysis system. Ciência e Agrotecnologia, Lavras, v. 35, n. 6 , p. 1039-1042, 2011. http://dx.doi.org/10.1590/S1413-70542011000600001

GAMA, P. E.; GIL, R. A. S. S.; LACHTER, E. R. Produção de biodiesel através de transesterificação in situ de sementes de girassol via catálise homogênea e heterogênea. Química Nova, São Paulo, v. 33, n. 9, 1859-1862, 2010. http://dx.doi.org/10.1590/S0100-40422010000900007

GONTIJO NETO, M. M.; LEITE, C. E. P.; UBA, M. A.; VASCONCELOS, F. V.; PEREIRA FILHO, I. A.; CRUZ, J. C. Avaliação de girassol e forrageiras tropicais perenes em cultivo consorciado. (Boletim de Pesquisa e Desenvolvimento / Embrapa Milho e Sorgo) Sete Lagoas, 2009, 1-16p.

GOMES, E. P.; ÁVILA, M. R.; RICKLI, M. E.; PETRI, F.; FEDRI, G. Desenvolvimento e produtividade do girassol sob lâminas de irrigação em semeadura direta na região do Arenito Caiuá, Estado do Paraná. Irriga, Botucatu, v. 15, n. 4, p. 373-385, 2010.

LIMA JÚNIOR, I. S. DE; BERTONCELLO, T. F.; MELO, E. P.; DEGRANDE, P. E.; KODAMA, C. Desfolha artificial simulando danos de pragas na cultura do girassol (Helianthus annuus L., Asteraceae). Revista Ceres, Viçosa, v. 57, p. 23-27, 2010. http://dx.doi.org/10.1590/S0034-737X2010000100005

LOBO, T. F.; GRASSI FILHO, H.; COELHO, H. A. Efeito da adubação nitrogenada na produtividade do girassol. Científica, Jaboticabal, v. 40, n. 1, p. 59-68, 2012.

KARADOĐAN, T.; AKGÜN, Í. Effect of leaf removal on sunflower yield and yield components and some quality characters. Helia, Novi Sad, v. 32, p. 123-134, 2009. http://dx.doi.org/10.2298/HEL0950123K

MACHADO, L. A. Z.; VALLE, C. B. Desempenho agronômico de genótipos de capim-braquiária em sucessão à soja. Pesquisa Agropecuária Brasileira, Brasília, v. 46, n. 11, p. 1454-1462, 2011.

http://dx.doi.org/10.1590/S0100-204X2011001100006

MAIA, G. A.; COSTA, K. A. P.; SEVERIANO, E. C.; EPIFANIO, P. S.; FLÁVIO NETO, J.; RIBEIRO, M. G.; FERNANDES, P. B.; SILVA, J. F. G.; GONÇALVES, W. G. Yield and Chemical composition of Brachiaria forage grasses in the offseason after corn harvest. American Journal of Plant Sciences, China, $\mathrm{n}$. 5, p. 933-941, 2014.

PARIZ, C. M.; ANDREOTTI, M.; AZENHA, M. V.; BERGAMASCHINE, A. F.; MELLO, L. M. M.; LIMA, R. C. Massa seca e composição bromatológica de quatro espécies de braquiárias semeadas na linha ou a lanço, em consórcio com milho no sistema plantio direto na palha. Acta Scientiarum Animal Sciences, Maringá, v. 32, n. 2, p. 147-154, 2010. http://dx.doi.org/10.4025/actascianimsci.v32i2.8498

PARIZ, C. M.; ANDREOTTI, M.; BERGAMASCHINE, A. F.; BUZETTI, S.; COSTA, N. R.; CAVALLINI, M. C. Produção, composição bromatológica e índice de clorofila de braquiárias após o consórcio com milho. Archivos de Zootecnia, Córdoba, v. 60, n. 232, p. 1041-1052, 2011. http://dx.doi.org/10.4321/S000405922011000400020

SANTOS, E. R.; BARROS, H. B. CAPONE, A.; FERRAZ, E. C.; FIDELIS, R. R. Efeito de épocas de semeadura sobre cultivares de girassol, no Sul do Estado do Tocantins. Ciência Agronômica, Fortaleza, v. 43 n. 1, p. 199-206, 2012. http://dx.doi.org/10.1590/S1806-66902012000100025

SILVA, D. J.; QUEIROZ, A. C. Análise de alimentos (métodos químicos e biológicos). 3. ed. Viçosa: Imprensa Universitária da UFV, 2002. 235 p. 
SOUZA, F. R.; SILVA, I. M.; PELLIN, D. M. P.; BERGAMIN, A. C.; SILVA, R. P. Características agronômicas do cultivo de girassol consorciado com Brachiaria ruziziensis. Revista Ciência Agronômica, Fortaleza, v. 46, n. 1, p. 110-116, 2015. http://dx.doi.org/10.1590/S1806-66902015000100013

TILLEY, J. M. A.; TERRY, R. A. A two stage technique for in vitro digestion of forages crops. Journal of the British Grassland Society, v. 18, p. 104-111, 1963. http://dx.doi.org/10.1111/j.1365-2494.1963.tb00335.x

UCHÔA, S. C. P.; IVANOFF, M. E. A.; ALVES, J. M. A.; SEDIYAMA, T.; MARTINS, S. A. Adubação de potássio em cobertura nos componentes de produção de cultivares de girassol. Revista Ciência Agronômica, Fortaleza, v. 42, n. 1, p. 8-15, 2011. http://dx.doi.org/10.1590/S1806-66902011000100002 